\title{
Tungsten Chemistry in Alkali Chloride Melts
}

\author{
Danil A. Danilov, Vladimir A. Volkovicha ${ }^{\mathrm{a}}$, Boris D. Vasin ${ }^{\mathrm{a}}$, Ilya B. Polovov ${ }^{\mathrm{a}}$, and \\ Trevor R. Griffiths ${ }^{b}$ \\ a Department of Rare Metals, Ural State Technical University, 620002 Ekaterinburg, Russia \\ ${ }^{\mathrm{b}}$ Redston Trevor Consulting Limited, Leeds, LS17 8RF, United Kingdom \\ Reprint requests to Dr. V. A. V.; E-mail: volkovich@dpt.ustu.ru
}

Z. Naturforsch. 62a, 739 - 744 (2007); received May 30, 2007

Presented at the EUCHEM Conference on Molten Salts and Ionic Liquids, Hammamet, Tunisia, September 16-22, 2006.

\begin{abstract}
Speciation of tungsten in alkali chloride melts (based on $\mathrm{NaCl}-2 \mathrm{CsCl}, \mathrm{NaCl}-\mathrm{KCl}$ and $3 \mathrm{LiCl}-2 \mathrm{KCl}$ mixtures) was studied between 550 and $750{ }^{\circ} \mathrm{C}$ using electronic absorption spectroscopy. Only W(IV) and $\mathrm{W}(\mathrm{V})$ chloro and oxychloro species can be stabilized under the conditions studied. Tungsten(IV) chloride ions are very sensitive to oxide/hydroxide impurities present in the melt. Anodic dissolution of $\mathrm{W}$ metal at anodic current densities in the range of $0.005-0.1 \mathrm{~A} / \mathrm{cm}^{2}$ produces only $\left[\mathrm{WCl}_{6}\right]^{2-}$ ions that can be electrochemically (on a glassy carbon anode) oxidized to $\left[\mathrm{WCl}_{6}\right]^{-}$. Small amounts of oxide ions present in the melt result in a gradual conversion of W(IV) chloro species into W(IV) oxychloro species. In the presence of $\mathrm{O}_{2}$ in the atmosphere $\left[\mathrm{WCl}_{6}\right]^{2-}$ is oxidized into the tungsten $(\mathrm{V})$ species $\left[\mathrm{WOCl}_{5}\right]^{2-}$. Dissolution of tungsten hexachloride, $\mathrm{WCl}_{6}$, in an $\mathrm{NaCl}-2 \mathrm{CsCl}$ melt initially yields $\left[\mathrm{WCl}_{6}\right]^{2-}$ (due to disproportionation). Reaction of metallic tungsten with $\mathrm{Pd}(\mathrm{II})$-containing melts results in the formation of $\left[\mathrm{WCl}_{6}\right]^{2-}$ species. The main spectroscopic parameters of $\left[\mathrm{WCl}_{6}\right]^{2-}$ and $\left[\mathrm{WCl}_{6}\right]^{-}$complex ions were calculated.
\end{abstract}

Key words: Tungsten; Tungsten Chlorides; Chloride Melts; Electronic Absorption Spectroscopy.

\section{Introduction}

Solutions of tungsten chlorides and oxychlorides in fused alkali chlorides can be used for producing tungsten powders and tungsten electroplating. Optimization of such processes requires detailed knowledge of speciation of tungsten in alkali chloride melts. Electronic absorption spectroscopy (EAS) is one of the prospective techniques for investigating speciation of ions of transition metals with partially filled d orbitals, including tungsten. Existing open literature lacks information concerning EAS of tungsten in alkali chloride melts, and there is a limited number of works dealing with the behaviour of tungsten chloro species in other ionic media.

Schoebrechts et al. [1] studied the dissolution of $\mathrm{WCl}_{6}$ in molten chloroaluminates and reported the formation of $\mathrm{WOCl}_{4}$ due to the presence of oxide ion impurities. Dissolution of $\mathrm{K}_{2} \mathrm{WCl}_{6}$ in a $3 \mathrm{LiCl}-2 \mathrm{KCl}$ eutectic [2] led to the formation of predominantly $\left[\mathrm{WCl}_{6}\right]^{2-}$ ions. Addition of sodium oxide to such a melt resulted in the transformation of $\left[\mathrm{WCl}_{6}\right]^{2-}$ into $\left[\mathrm{W}_{2} \mathrm{OCl}_{10}\right]^{4-}$ and/or $\left[\mathrm{WOCl}_{5}\right]^{2-}$; upon increas- ing the $\mathrm{Na}_{2} \mathrm{O} / \mathrm{K}_{2} \mathrm{WCl}_{6}$ ratio to two tungsten dioxide, $\mathrm{WO}_{2}$, was precipitated. Mamantov et al. [3] prepared chloroaluminate melts containing $\mathrm{W}(\mathrm{IV})$ and $\mathrm{W}(\mathrm{V})$ species by dissolving $\mathrm{K}_{2} \mathrm{WCl}_{6}$ and $\mathrm{KWCl}_{6}$, respectively; the former compound had very low solubility. Dissolution of $\mathrm{WCl}_{4}, \mathrm{WCl}_{6}$ and $\mathrm{WOCl}_{4}$ in 1-butyl-3methylimidazolium tetrafluoroborate was investigated by Babushkina et al. [4] using EAS and IR spectroscopy. Tungsten tetrachloride dissolved forming initially $\left[\mathrm{WCl}_{4} \mathrm{~F}_{2}\right]^{2-}$ complex ions that then were transformed into $\left[\mathrm{WCl}_{4-n} \mathrm{~F}_{2+n}\right]^{2-}$.

In the present work high temperature EAS and diffuse reflectance spectroscopy were used to investigate the tungsten speciation in melts based on $\mathrm{NaCl}-2 \mathrm{CsCl}$ and $3 \mathrm{LiCl}-2 \mathrm{KCl}$ eutectics and an $\mathrm{NaCl}-\mathrm{KCl}$ equimolar mixture at $550-750{ }^{\circ} \mathrm{C}$. The above melt compositions were chosen because they are often employed on industrial/semi-industrial scale.

\section{Experimental}

The experiments were performed in standard high temperature $1 \mathrm{~cm}$ path length silica optical cells, using 
the setup based on an Ocean Optics SD2000 double channel fibre optic spectrometer and optical furnace described earlier [5]. Spectral data were collected in the range of $250-1100 \mathrm{~nm}\left(40000-9000 \mathrm{~cm}^{-1}\right)$. Alkali metal chloride mixtures were prepared in the following way. Reagent grade alkali chlorides [A.C.S. $(99+\%)$ for $\mathrm{LiCl}, \mathrm{NaCl}$ and $\mathrm{KCl}$, and 99.99 for $\mathrm{CsCl}]$ were dried for $4-5 \mathrm{~h}$ under vacuum at $300{ }^{\circ} \mathrm{C}$. The temperature was then risen above the melting point of the corresponding salt, and the liquid salt was further kept under vacuum for $2-3 \mathrm{~h}$. Dried salts were mixed in the required proportion, fused under vacuum, the cell was then filled with argon and the melt bubbled with dry hydrogen chloride (for $4 \mathrm{~h}$ ) to convert any oxide/hydroxide impurities into chlorides. The cell was then again evacuated (to remove dissolved $\mathrm{HCl}$ ) and filled with argon. Obtained salt mixtures were further purified using zone melting (6-8 times) under vacuum. Anhydrous tungsten hexachloride (reagent grade, $\mathrm{BDH})$ was stored and manipulated in a dry box. Mixture of $\mathrm{PdCl}_{2}$ and $\mathrm{NaCl}-2 \mathrm{CsCl}$ was prepared by anodic dissolution of metallic palladium in the sodiumcaesium chloride eutectic melt under argon. Argon used throughout this study was additionally purified by passing through zirconium turnings at $800{ }^{\circ} \mathrm{C}$.

Experiments were performed in standard $1 \mathrm{~cm}$ optical silica cells, attached to a silica tube (ca. $25 \mathrm{~cm}$ long) with two side-arms in the upper part. The cell was loaded with ca. $8 \mathrm{~g}$ of a chosen alkali chloride mixture. One side-arm of the cell was connected to the vacuum/argon line and the other used (if required) to discharge outgoing gaseous reagents through conc. sulphuric acid. The cell was closed with a rubber stopper containing the required electrodes (for anodic dissolution and spectroelectrochemistry experiments) or a moveable vertical silica tube (3 $\mathrm{mm}$ i.d.) for introducing $\mathrm{Cl}_{2}$ into the melt. The stoppered cell was evacuated, placed into the optical furnace (Instron SFL Model TF 1726 with an Omega CN76000 controller) thermostated at a desired temperature and the salts were melted. The cell was then filled with argon. If experiments involved chlorination a constant stream of gaseous $\mathrm{Cl}_{2}$ (prepared by electrolysis of fused lead chloride) was introduced into the cell.

After measuring reference spectra of the pure solvent melt, tungsten species were added into the melt. Tungsten was introduced into the melt in various ways: by anodic dissolution of $\mathrm{W}$ metal, reacting $\mathrm{W}$ powder with $\mathrm{Cl}_{2}$ in the melt, by reacting metallic tungsten with $\operatorname{Pd}(\mathrm{II})$-containing melts and by direct dissolution of tungsten hexachloride, $\mathrm{WCl}_{6}$. Tungsten powder and an $\mathrm{NaCl}-2 \mathrm{CsCl}+\mathrm{PdCl}_{2}$ mixture were introduced into the melt after recording the reference spectra using a special loading device without disturbing the inert atmosphere in the cell. Apart from chlorination of tungsten, all the experiments were performed under argon atmosphere. For anodic dissolution a piece of tungsten foil was used as an anode; a molybdenum wire in molten lead chloride separated from the bulk of the melt by a silica capillary tube with a diaphragm served as a cathode. For spectroelectrochemical measurements the optical cell also contained a glassy carbon working electrode and an $\mathrm{Ag} / \mathrm{AgCl}(1 \mathrm{~mol} \%$ in $\mathrm{NaCl}-2 \mathrm{CsCl})$ reference electrode. A PI-50-1.1 potentiostat was used for all the electrochemical measurements. Melt samples sucked from the melts into silica capillary tubes using a syringe and rapidly quenched under argon were analysed to determine the tungsten content (photometrically with thiocyanate) and average oxidation state of tungsten (oxidimetrically). Experimental spectra were resolved into individual overlapping bands using PeakFit version 4.01 software.

\section{Results and Discussion}

The rate of reaction of tungsten powder with chlorine in the $\mathrm{NaCl}-2 \mathrm{CsCl}$ melt at $600{ }^{\circ} \mathrm{C}$ was high, and the melt became dark red. Analysis of the quenched melt showed that the average oxidation state of tungsten was 5.0. Resolution of the recorded spectrum into individual bands, Fig. 1, revealed one absorption band with the maximum at $12600 \mathrm{~cm}^{-1}$. The spectrum thus can be attributed to the absorption of the tungsten $(\mathrm{V})$ chloride complex, $\left[\mathrm{WCl}_{6}\right]^{-}$, and the band

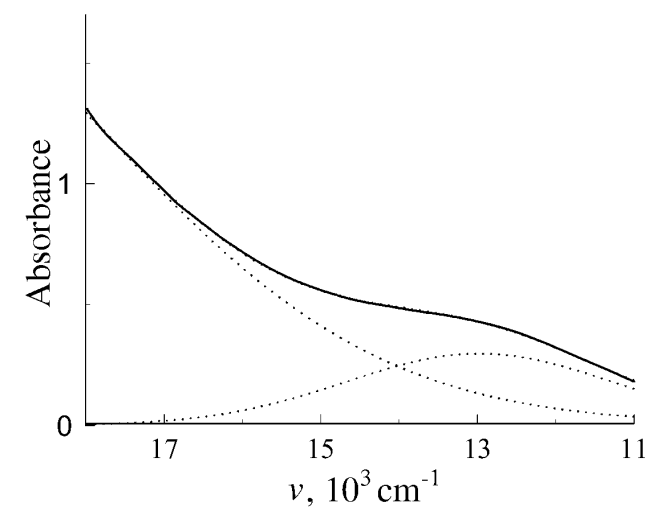

Fig. 1. Electronic absorption spectrum of an $\mathrm{NaCl}-2 \mathrm{CsCl}$ melt containing products of chlorination of $\mathrm{W}$ metal powder by $\mathrm{Cl}_{2}$ at $600{ }^{\circ} \mathrm{C} ; \mathrm{W}$ concentration: $0.06 \mathrm{~mol} / \mathrm{dm}^{3}$. 


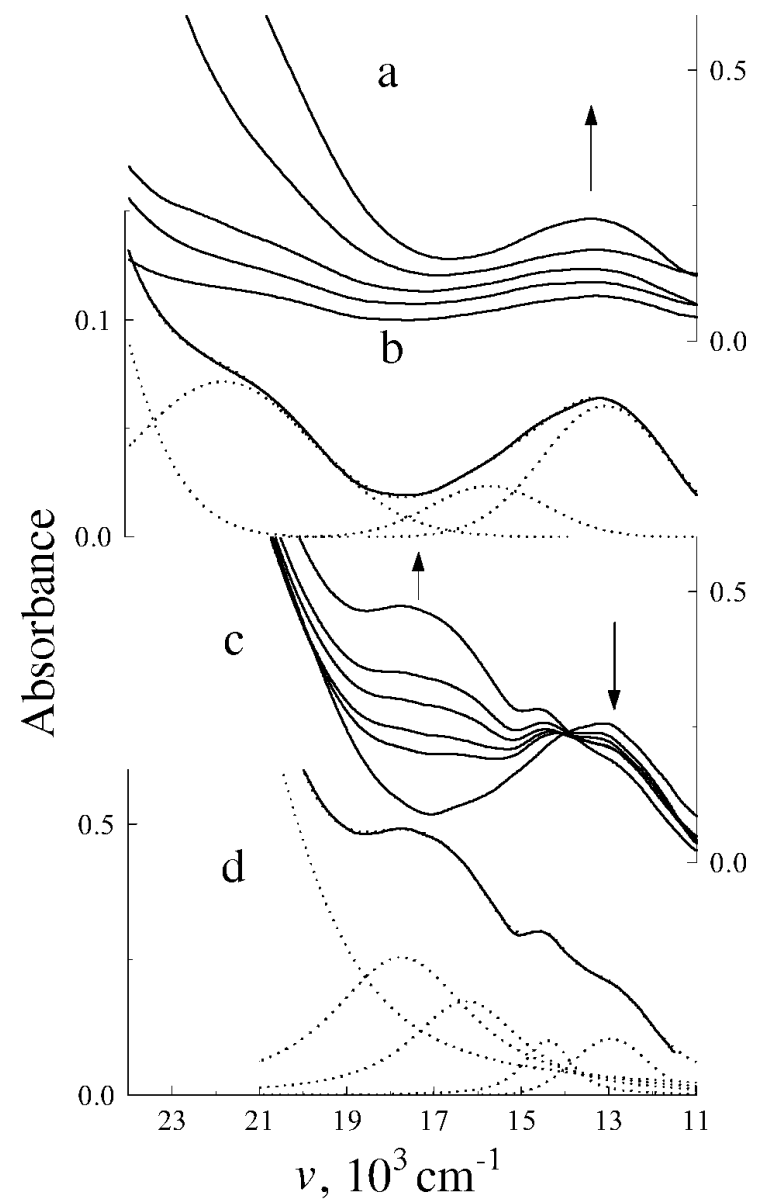

Fig. 2. Spectra recorded during anodic dissolution of $\mathrm{W}$ in an $\mathrm{NaCl}-2 \mathrm{CsCl}$ melt at $550{ }^{\circ} \mathrm{C}(\mathrm{a}, \mathrm{b})$ and during holding the melt in a silica cell under an $\mathrm{Ar}$ atmosphere (c, d); final W concentration: $0.03 \mathrm{~mol} / \mathrm{dm}^{3}$.

at $12600 \mathrm{~cm}^{-1}$ originated from the ${ }^{2} \mathrm{~T}_{2 \mathrm{~g}} \rightarrow{ }^{2} \mathrm{E}_{\mathrm{g}}$ electronic transition in this complex ( $\mathrm{d}^{1}$ configuration). $D q$ thus equals to $1260 \mathrm{~cm}^{-1}$. The spectrum also contains a low-energy edge of an intense charge-transfer band, the maximum of which (due to very high absorption) could not be detected using the present setup.

Anodic dissolution of tungsten in the $\mathrm{NaCl}-2 \mathrm{CsCl}$ eutectic at $550{ }^{\circ} \mathrm{C}$ at anodic current densities of $0.005-$ $0.1 \mathrm{~A} / \mathrm{cm}^{2}$ resulted in emerald-green melts. The average oxidation state of tungsten determined in samples taken immediately after completing the anodic dissolution ranged from 4.0 to 4.3 . The spectra recorded during the anodic dissolution at an anodic current density of $0.1 \mathrm{~A} / \mathrm{cm}^{2}$ are presented in Fig. 2a; spectra obtained at other used current densities were similar. Resolution of one of the spectra into individ-

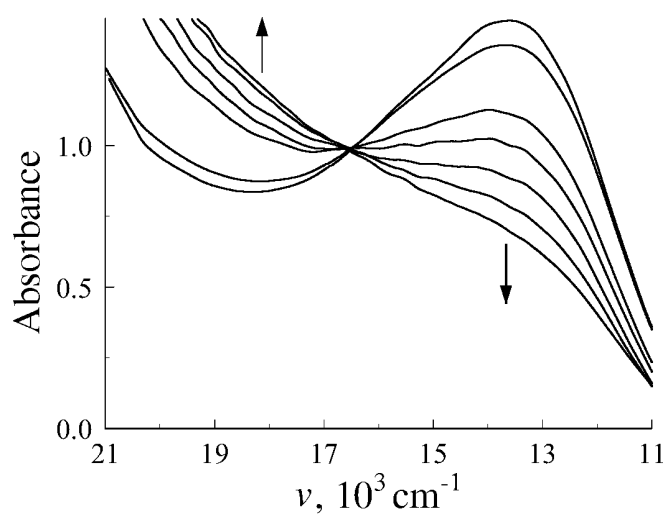

Fig. 3. Spectra recorded during oxidation of $\left[\mathrm{WCl}_{6}\right]^{2-}$ by $\mathrm{O}_{2}$ in an $\mathrm{NaCl}-2 \mathrm{CsCl}$ melt at $550{ }^{\circ} \mathrm{C}$; final $\mathrm{W}$ concentration: $0.05 \mathrm{~mol} / \mathrm{dm}^{3}$.

ual bands, Fig. 2b, revealed three absorption bands. These were attributed to the electronic transitions in the $\left[\mathrm{WCl}_{6}\right]^{2-}$ complex ion $\left(\mathrm{d}^{2}\right.$ configuration $),{ }^{3} \mathrm{~T}_{1 \mathrm{~g}} \rightarrow$ ${ }^{3} \mathrm{~T}_{2 \mathrm{~g}}\left(13100 \mathrm{~cm}^{-1}\right),{ }^{3} \mathrm{~T}_{1 \mathrm{~g}} \rightarrow{ }^{3} \mathrm{~T}_{1 \mathrm{~g}}(\mathrm{P})\left(21800 \mathrm{~cm}^{-1}\right)$; a weaker band at $15800 \mathrm{~cm}^{-1}$ originated, presumably, from one of the spin-forbidden transitions. $D q$ and $B$ values were calculated as 1400 and $690 \mathrm{~cm}^{-1}$, respectively.

Holding a $\left[\mathrm{WCl}_{6}\right]^{2-}$-containing melt (both in contact with metallic $\mathrm{W}$ and without it) under argon resulted in a gradual change of the colour (to greenishyellow) and the spectral profiles (Fig. 2c). An isosbestic point was observed at $14000 \mathrm{~cm}^{-1}$, showing that two species were present in the melt, and the total concentration of tungsten remained unchanged. Resolution of the spectrum recorded $20 \mathrm{~min}$ after completing the anodic dissolution is shown in Figure 2d. The spectrum consists of four bands at 17800, 16300, 14400 and $13000 \mathrm{~cm}^{-1}$. Chemical analysis showed that the oxidation state of tungsten in the melt did not change and remained around four, indicating that most likely a W(IV) oxychloro species was formed due to reaction of $\left[\mathrm{WCl}_{6}\right]^{2-}$ with oxide species. Calculations showed that this reaction followed the zeroorder kinetics with respect to $\left[\mathrm{WCl}_{6}\right]^{2-}$, and the rate constant was $8 \cdot 10^{-6} \mathrm{~mol} /(\mathrm{l} \cdot \mathrm{s})$. Unfortunately the exact nature of the W(IV) oxychloro species formed in the melt could not be established; the spectra shown in Fig. 2c most likely correspond to the presence of $\left[\mathrm{WCl}_{6}\right]^{2-}$ and one of the following $-\left[\mathrm{WOCl}_{5}\right]^{3-}$ or $\left[\mathrm{W}_{2} \mathrm{OCl}_{10}\right]^{4-}$ in the melt. The oxide species could result from impurities present in the melt, but more likely the source of the oxide ions was the silica of the cell. After performing several experiments in a new 


\begin{tabular}{|c|c|c|c|c|}
\hline Melt & $T,{ }^{\circ} \mathrm{C}$ & Method of tungsten addition & $\begin{array}{l}\text { Tungsten species } \\
\text { formed }\end{array}$ & $\begin{array}{l}\text { Band maxima, } \\
\mathrm{cm}^{-1}\end{array}$ \\
\hline $\mathrm{NaCl}-2 \mathrm{CsCl}$ & 600 & W powder chlorination & {$\left[\mathrm{WCl}_{6}\right]^{-}$} & 12600 \\
\hline $\mathrm{NaCl}-2 \mathrm{CsCl}$ & 550 & W anodic dissolution & {$\left[\mathrm{WCl}_{6}\right]^{2-}$} & $\begin{array}{l}21800 \\
15800 \\
13100\end{array}$ \\
\hline $\mathrm{NaCl}-2 \mathrm{CsCl}$ & 550 & $\begin{array}{l}\text { Melt after W anodic dissolution } \\
\text { held in a silica cell under Ar at- } \\
\text { mosphere }\end{array}$ & $\begin{array}{l}{\left[\mathrm{W}_{x} \mathrm{OCl}_{5 x}\right]^{-2-x}} \\
{\left[\mathrm{~W}_{x} \mathrm{OCl}_{5 x}\right]^{-2-x}} \\
\text { and }\left[\mathrm{WCl}_{6}\right]^{2-}\end{array}$ & $\begin{array}{l}17800 \\
16300 \\
14400 \\
13000\end{array}$ \\
\hline $\mathrm{NaCl}-2 \mathrm{CsCl}$ & 550 & $\begin{array}{l}\text { Melt after W anodic dissolution } \\
\text { held in a silica cell under } \mathrm{Ar}+ \\
\text { air atmosphere }\end{array}$ & $\begin{array}{l}{\left[\mathrm{WOCl}_{5}\right]^{2-}} \\
{\left[\mathrm{WCl}_{6}\right]^{2-}}\end{array}$ & $\begin{array}{l}>22000 \\
15600 \\
13000\end{array}$ \\
\hline $3 \mathrm{LiCl}-2 \mathrm{KCl}$ & 550 & $\mathrm{~W}$ anodic dissolution & {$\left[\mathrm{W}_{x} \mathrm{OCl}_{5 x}\right]^{-2-x}$} & $\begin{array}{l}18000 \\
16400\end{array}$ \\
\hline & & & $\begin{array}{l}{\left[\mathrm{W}_{x} \mathrm{OCl}_{5 x}\right]^{-2-x}} \\
\text { and }\left[\mathrm{WCl}_{6}\right]^{2-}\end{array}$ & $\begin{array}{l}14500 \\
13100\end{array}$ \\
\hline $\mathrm{NaCl}-\mathrm{KCl}$ & 750 & $\mathrm{~W}$ anodic dissolution & {$\left[\mathrm{W}_{x} \mathrm{OCl}_{5 x}\right]^{-2-x}$} & $\begin{array}{l}17800 \\
16000\end{array}$ \\
\hline & & & $\begin{array}{l}{\left[\mathrm{W}_{x} \mathrm{OCl}_{5 x}\right]^{-2-x}} \\
\text { and }\left[\mathrm{WCl}_{6}\right]^{2-}\end{array}$ & $\begin{array}{l}14000 \\
12200\end{array}$ \\
\hline $\mathrm{NaCl}-2 \mathrm{CsCl}$ & 550 & $\begin{array}{l}\text { Direct dissolution of } \mathrm{WCl}_{6} \\
\text { ( } \mathrm{HCl} \text { atmosphere })\end{array}$ & $\begin{array}{l}{\left[\mathrm{WOCl}_{5}\right]^{2-}} \\
{\left[\mathrm{W}_{x} \mathrm{OCl}_{5 x}\right]^{-2-x}}\end{array}$ & $\begin{array}{l}>22000 \\
17700 \\
15800\end{array}$ \\
\hline & & & $\begin{array}{l}{\left[\mathrm{W}_{x} \mathrm{OCl}_{5 x}\right]^{-2-x}} \\
\text { and }\left[\mathrm{WCl}_{6}\right]^{2-}\end{array}$ & $\begin{array}{l}14100 \\
12500\end{array}$ \\
\hline $\mathrm{NaCl}-2 \mathrm{CsCl}$ & 600 & $\begin{array}{l}\text { Reaction of W with }\left[\mathrm{PdCl}_{6}\right]^{4-} \\
\text { containing melt }\end{array}$ & $\begin{array}{l}{\left[\mathrm{PdCl}_{6}\right]^{4-}} \\
{\left[\mathrm{W}_{x} \mathrm{OCl}_{5 x}\right]^{-2-x}}\end{array}$ & $\begin{array}{l}18600 \\
17400 \\
16100\end{array}$ \\
\hline & & & $\begin{array}{l}{\left[\mathrm{W}_{x} \mathrm{OCl}_{5 x}\right]^{-2-x}} \\
\text { and }\left[\mathrm{WCl}_{6}\right]^{2-}\end{array}$ & $\begin{array}{l}14400 \\
12800 \\
\end{array}$ \\
\hline
\end{tabular}

Table 1. Results of the spectroscopic studies of tungsten species in alkali chloride-based melts. cell it could be seen that silica is affected by W(IV)containing melts, having very high affinity for oxygen species.

Holding a $\left[\mathrm{WCl}_{6}\right]^{2-}$-containing melt under an oxygen-containing atmosphere (oxygen was introduced into the cell through a syringe needle passed through the rubber cell stopper) resulted in different changes in the spectra (Fig. 3). Absorbance between $12500-15000 \mathrm{~cm}^{-1}$ decreased and an isosbestic point was formed at $16500 \mathrm{~cm}^{-1}$, again showing that the total concentration of tungsten in the melt remained the same. Analysis of the quenched melts showed that an oxychloro complex of $\mathrm{W}(\mathrm{V}),\left[\mathrm{WOCl}_{5}\right]^{2-}$, was formed this time, and the average oxidation state of tungsten was 5.1. This reaction of $\left[\mathrm{WCl}_{6}\right]^{2-}$ with oxygen leading to the formation of $\left[\mathrm{WOCl}_{5}\right]^{2-}$ followed first-order kinetics with respect to $\left[\mathrm{WCl}_{6}\right]^{2-}$ and the rate constant was $8 \cdot 10^{-4} \mathrm{~s}^{-1}$.

Spectra recorded during anodic dissolution of tungsten in a $3 \mathrm{LiCl}-2 \mathrm{KCl}$ melt at $550{ }^{\circ} \mathrm{C}$ contained bands of both chloro- and oxychloro complexes of W(IV). The average oxidation state of tungsten was around 4.2. The results of the resolution of the spectra into individual bands are given in Table 1 .

Spectra measured in the course of anodic dissolution of $\mathrm{W}$ metal in a $\mathrm{NaCl}-\mathrm{KCl}$ melt at $750{ }^{\circ} \mathrm{C}$ are shown in Figure 4a. As the concentration of tungsten in the melt increased, the maximum of the spectrum shifted towards higher energy values. After the anodic dissolution was finished, the melt was held in the cell and the maximum in the spectrum shifted in the opposite direction (Fig. 4b). Such behaviour can be explained by the coexistence of tungsten(IV) chloro- and oxychloro species in the melt. Subtracting the final spectral curve in Fig. 4b from the final spectral curve after anodic dissolution in Fig. 4a produced a spectrum (shown in Fig. 4c together with the resolution into individual bands) that was earlier attributed to a W(IV) oxychloro complex. Therefore the changes in the spectra observed in Fig. 4b occurred because the concentra- 


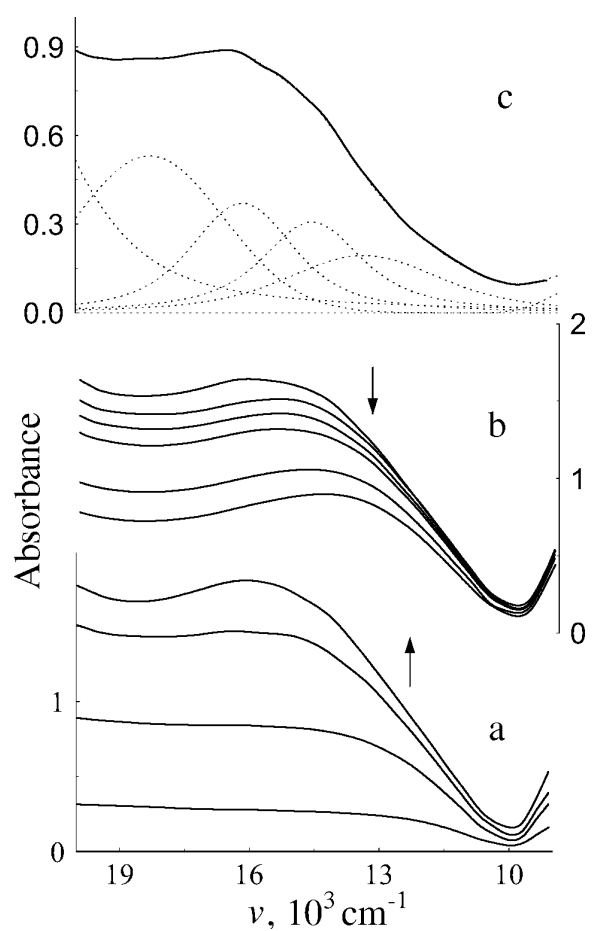

Fig. 4. Spectra recorded in the course of anodic dissolution of tungsten in an $\mathrm{NaCl}-\mathrm{KCl}$ melt (a) and during holding this melt under argon (b). (c) Spectrum of the difference between the last spectrum in (a) and the last spectrum in (b). Temperature: $750{ }^{\circ} \mathrm{C}$; final $\mathrm{W}$ concentration: $0.02 \mathrm{~mol} / \mathrm{dm}^{3}$.

tion of the oxychloro species gradually decrease (probably due to the volatile nature of tungsten oxychlorides at high temperatures). Oxidimetric analysis of the quenched melt showed that the average oxidation state of tungsten was 4.2.

Direct addition of tungsten hexachloride to an $\mathrm{NaCl}-2 \mathrm{CsCl}$ melt at $550{ }^{\circ} \mathrm{C}$ under an $\mathrm{HCl}$ atmosphere resulted in the formation of a dark red melt, which after a few minutes became emerald-green. Subsequent changes of the spectra with time were analogous to those in Fig. 3; an isosbestic point was formed at $16500 \mathrm{~cm}^{-1}$. The average oxidation state of tungsten in the final melt was 5.3. In this case the changes in the spectra were due to the oxidation of W(IV) (formed as a result of disproportionation of $\mathrm{WCl}_{6}$ ) to an oxychloro complex of $\mathrm{W}(\mathrm{V})$. The final spectrum was the superposition of the absorption bands of $\left[\mathrm{WOCl}_{5}\right]^{2-}$ and $\left[\mathrm{WCl}_{6}\right]^{2-}$.

Palladium(II), forming $\left[\mathrm{PdCl}_{6}\right]^{4-}$ ions, was used as a "soft" oxidant for $\mathrm{W}$ metal in an attempt to see if lower oxidation states of tungsten could be obtained in chloride melts. Metallic tungsten was reacted with a $\mathrm{NaCl}-2 \mathrm{CsCl}$ melt containing palladium dichloride at $600{ }^{\circ} \mathrm{C}$. The ruby-red colour of the melt (due to $\left[\mathrm{PdCl}_{6}\right]^{4-}$ ) slowly changed to green, and a dendritic deposit of metallic palladium was formed on the tungsten plate surface. Analysis of the final melt and the recorded spectra, however, showed that the main product of this reaction was again an oxychloro complex of tungsten(IV). The result of resolution of the final spectrum into individual bands is presented in Table 1.

A series of spectroelectrochemical experiments was performed in $\mathrm{NaCl}-2 \mathrm{CsCl}$ melts to see if tungsten ions containing $\mathrm{W}$ in an oxidation state other than four can be generated electrochemically. Potentiometric measurements [6,7] showed that in $\mathrm{NaCl}-\mathrm{KCl}-$ based melts $\mathrm{W}(\mathrm{IV})$ and $\mathrm{W}(\mathrm{V})$ chloride complexes are stable, and, based on the results of polarization studies, Mannenkov and Shkol'nikov [7] suggested a three-stage reduction mechanism for tungsten species: $\mathrm{W}(\mathrm{V}) \rightarrow \mathrm{W}(\mathrm{IV}) \rightarrow \mathrm{W}(\mathrm{II}) \rightarrow \mathrm{W}(0)$. Proposed lower oxidation state tungsten species, W(II) or W(III) [7,8], have very low solubility in chloride melts, and this results in passivation of the electrodes. Cyclic voltammetry (CV) studies in 3LiCl-2 KCl melts [2] however showed that W(IV) ions can be reduced to metallic tungsten in a single four-electron step. In the literature, therefore, there is no single opinion concerning the existence of low oxidation state tungsten chloro species in fused salts. Tungsten-containing chloride melts held in contact with oxygen-containing materials (like silica) essentially always contain oxychloro species [9], and this further complicates the interpretation of results of experimental measurements.

In the present study metallic tungsten was initially anodically dissolved in alkali chloride melts, producing $\left[\mathrm{WCl}_{6}\right]^{2-}$ ions. An example of a cyclic voltammogram of a $\left[\mathrm{WCl}_{6}\right]^{2-}$-containing melt, measured at various scan rates at $600{ }^{\circ} \mathrm{C}$, is shown in Figure 5. On the time scale of the $\mathrm{CV}$ measurements the reaction of W(IV) ions with silica can be neglected. As was shown above, metallic tungsten anodically dissolves in chloride melts forming W(IV) species. Two anodic waves in the cyclic voltammogram were therefore ascribed to $\mathrm{W}(0) \rightarrow \mathrm{W}(\mathrm{IV})$ and $\mathrm{W}(\mathrm{IV}) \rightarrow \mathrm{W}(\mathrm{V})$ reactions. Potentiostatic electrolysis at $+1.0 \mathrm{~V}$ resulted in gradual changes in the spectra, Fig. 6, the absorbance at around $12500 \mathrm{~cm}^{-1}$ [corresponding to $\mathrm{W}(\mathrm{V})$, cf. Fig. 1] was increasing and above $15500 \mathrm{~cm}^{-1}$ decreasing. An isosbestic point in the spectra indicates that the total concentration of tungsten in the melt did not change appreciably. After 160 min of oxidation the av- 


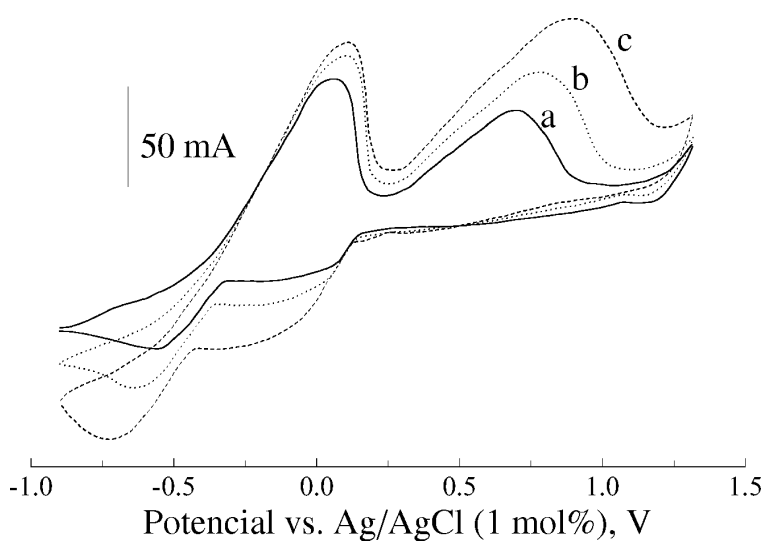

Fig. 5. Cyclic voltammogram of a $\left[\mathrm{WCl}_{6}\right]^{2-}$-containing $\mathrm{NaCl}-2 \mathrm{CsCl}$-based melt at $600{ }^{\circ} \mathrm{C}$ prepared by anodic dissolution of $\mathrm{W}$ metal. Working electrode: glassy carbon; reference electrode: $\mathrm{Ag} / \mathrm{AgCl}(1 \mathrm{~mol} \%$ in $\mathrm{NaCl}-2 \mathrm{CsCl})$; counter electrode: molybdenum wire in $\mathrm{NaCl}-2 \mathrm{CsCl}+\mathrm{PbCl}_{2}$; rest potential: $+0.3 \mathrm{~V}$; $\mathrm{W}$ content: $0.34 \mathrm{wt} \%$; scan rates: (a) 0.1 , (b) 0.2 and (c) $0.5 \mathrm{~V} / \mathrm{s}$.

erage oxidation state of tungsten in the melt changed from 4 to 4.4 , thus confirming the $\mathrm{W}(\mathrm{IV}) \rightarrow \mathrm{W}(\mathrm{V})$ oxidation and accumulation of $\left[\mathrm{WCl}_{6}\right]^{-}$ions in the melt. Similar results were obtained when the anodic oxidation was conducted at potentials from +0.8 to $+1.15 \mathrm{~V}$ at $550-600{ }^{\circ} \mathrm{C}$.

Interpretation of the cathodic part of the cyclic voltammogram in Fig. 5 is not straightforward. Two cathodic waves were initially tentatively attributed to $\mathrm{W}(\mathrm{IV}) \rightarrow \mathrm{W}(\mathrm{III} / \mathrm{II})$ and $\mathrm{W}(\mathrm{III} / \mathrm{II}) \rightarrow \mathrm{W}(0)$ reactions. Attempts to potentiostatically reduce such melts at $-0.25 \mathrm{~V}$ to generate lower oxidation state tungsten ions were not successful, the concentration of W(IV) in the melt decreased over time, but no new additional peaks in the spectra appeared. The final melt contained a grey precipitate that could be metallic tungsten

[1] J.-P. Schoebrechts, P. A. Flowers, G. W. Hance, and G. Mamantov, J. Electrochem. Soc. 135, 3057 (1988).

[2] C. Hasiotis and T. Ostvold, Acta Chem. Scand. 52, 1322 (1998).

[3] G. Mamantov, G.-S. Chen, H. Xiao, Y. Yang, and E. Hondrogiannis, J. Electrochem. Soc. 142, 1758 (1995).

[4] O. Babushkina, M. Siam, J. O. Besenhard, G. Fafilek, H. Kronberger, and G. E. Nauer, in: Proceedings of the International Symposium on Ionic Liquids, 26-28 June 2003, Carry le Rouet, France, p. 55.

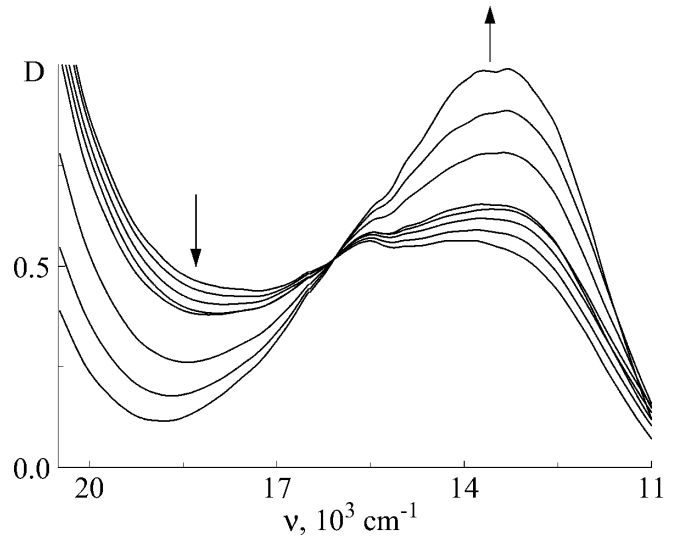

Fig. 6. Spectra recorded during potentiostatic oxidation of an NaCl-2CsCl-based melt containing $\left[\mathrm{WCl}_{6}\right]^{2-}$ ions at $600{ }^{\circ} \mathrm{C}$. W concentration: $0.34 \mathrm{wt} \%$; applied potential: $+1.0 \mathrm{~V}$ vs. $\mathrm{Ag} / \mathrm{AgCl}(1 \mathrm{~mol} \%)$; working electrode: glassy carbon; total duration of oxidation: $160 \mathrm{~min}$.

resulting from disproportionation of lower oxidation state tungsten species; this is not an uncommon phenomenon for transition metal ions in molten salts. Therefore we can conclude that the lowest oxidation state of tungsten that can be stabilized in the soluble form in molten alkali chlorides is most likely four.

\section{Conclusions}

The performed electronic absorption spectroscopy experiments showed that only W(IV) and W(V) chloro and oxychloro species can be stabilized in alkali metal chloride melts. This is different from molybdenum where the oxidation state of +3 is the most stable. Greater stability (compare to Mo) of tungsten oxychloro species in fused chlorides is due to the lower volatility of tungsten oxychlorides.

[5] V. A. Volkovich, I. May, J. M. Charnock, and B. Lewin, Phys. Chem. Chem. Phys. 4, 5753 (2002).

[6] S.N. Shkol'nikov, M.I. Mannenkov, and A. K. Yarmolovich, Zh. Prikl. Khim. 46, 1918 (1973).

[7] M. I. Mannenkov and S.N. Shkol'nikov, Izv. Vuzov: Tsvet. Met. 1, 65 (1974).

[8] G. Rubel and M. Gross, Corr. Sci. 15, 261 (1975).

[9] A. M. Molchanov, Electrodeposition of tungsten from halide melts, PhD Thesis, Institute of Electrochemistry, Sverdlovsk 1984, p. 149. 